\title{
Reducing the bloater spoilage incidence in fermented green olives during storage
}

\author{
By A. Asehraou ${ }^{1}$, C. Peres $^{2}$, M. Faid ${ }^{3}$ and D. Brito ${ }^{2}$ \\ ${ }^{1}$ Biology Department, Faculty of Sciences, Mohamed $1{ }^{\text {st }}$ University, BP: 524, Oujda, Morocco \\ e-mail: asehraou@sciences.univ-oujda.ac.ma. \\ ${ }^{2}$ Instituto Nacional de Investigaçao Agraria (INIA), Apt. 127, 2780 Oeiras, Portugal. \\ E-mail: cperes@itqb.unl.pt \\ ${ }^{3}$ Hassan II Institute of Agronomy and Veterinary Medicine, Department of Food Engineering \\ and Technology, BP: 6202, Rabat-Instituts, Morocco.
}

\section{RESUMEN}

Reducción de la incidencia de la alteración por alambrado en aceitunas verdes fermentadas durante su almacenamiento.

Aceitunas verdes fermentadas de la variedad Picholine fueron colocadas en soluciones de salmuera al $5 \%$ en $\mathrm{NaCl}$, ajustando el pH a 4,00 y 5,00 con ácido láctico. Se agregó sorbato potásico a la salmuera a una concentración del 0,05\% y las muestras se inocularon con cepas de Lactobacillus plantarum I159 y Pichia anomala S18 de nuestra procedencia. Los valores del pH y el recuento microbiano incluyendo a las bacterias Gram-negativas, levaduras y mohos y bacterias del ácido láctico se siguieron durante los seis meses de almacenamiento. Los resultados mostraron que incluso inoculando las aceitunas con la levadura ( $P$. anomala S18), productora de alta cantidad de gas, el ataque de los frutos por el alambrado se redujo drásticamente en las muestras ajustadas a pH 4 , a las que se añadió sorbato potásico e inoculó con Lactobacillus plantarum, sin verse afectadas las características organolépticas del producto.

PALABRAS-CLAVE: Aceituna de mesa - Alambrado - Lactobacillus plantarum - Levadura - Sorbato potásico.

\section{SUMMARY}

Reducing the bloater spoilage incidence in fermented green olives during storage.

Fermented green olives of the variety "Picholine" were brined in $5 \% \mathrm{NaCl}$ solutions, which were adjusted to $\mathrm{pH} 4.00$ and 5.00 with lactic acid. Potassium sorbate was added to the brine at $0.05 \%$ and the assays were inoculated with Lactobacillus plantarum strain I159, and Pichia anomala strains S18 from our collection. The $\mathrm{pH}$ values and microbial counts including Gram negative bacteria, yeasts and moulds, and lactic acid bacteria were followed during 6 months of storage. Results showed that even if the olives were inoculated with a high gas producing yeast ( $P$. anomala S18), the attack of the fruits by the "bloater" spoilage was drastically reduced in the assays adjusted to $\mathrm{pH} 4$, added with potassium sorbate and inoculated with L. plantarum, without affecting the organoleptic characteristics of the product.

KEY-WORDS: Table olives, Alambrado, Lactobacillus plantarum, Potassium sorbate, yeasts.

\section{INTRODUCTION}

Fermented green olives are usually washed, after the fermentation is achieved, and stored at $10 \%$ $\mathrm{NaCl}$ acidified to $\mathrm{pH} 4$ (Asehraou et al. 2000). These conditions, which are used in olive industry in Morocco, may lead to various deteriorations, especially softening, off-odours fermentations and the bloater spoilage (Garrido Fernandez et al., 1996).

The softening deterioration is due to the pectinolytic micro-organisms, including bacteria, yeasts and moulds. Off-odours fermentations are caused by Clostridium and Propionibacterium (Fleming, 1982). The control of $\mathrm{pH}$ and salt concentration in brine would prevent these defects (Gonzalez Cancho et al., 1970).

Bloater deterioration called "Alambrado" is the most frequent defect occurring in olives during storage. This deterioration is caused by the gas producing microorganisms, particularly yeasts during storage (Asehraou et al., 2000). The control of $\mathrm{pH}$ and salt concentration, which is the practice widely used in the olive industry, is not sufficient to prevent this defect during storage (Asehraou et al., 2000). This is due to the resistance of yeasts to high $\mathrm{NaCl}$ concentrations and low $\mathrm{pHs}$.

Olive fermentation and preservation (postfermentation) is governed by the nature and activity of lactic acid bacteria in comparison to the nature and activity of yeasts. The balance between these two microbial groups is the most important factor for the success of table olives production process. A succeded fermentation followed by a good storage may need a predominance of the biochemical activity of lactic acid bacteria on yeasts.

In a previous study (Asehraou et al., 1997), the use of essential oil from garlic was demonstrated to have an important effect in controlling the yeast population in brine and consequently a good preservation of the fermented olives, but the 
organoleptic characteristics of the product were affected by the garlic odour.

Potassium Sorbate is known to have a high inhibitory effect on yeasts and moulds without affecting the lactic population in fermented olives during storage (Marsilio and Cichelli. 1992). Thus, it would be an effective mean to control the yeast population responsible on the high level of the "bloater" spoilage formation in fermented olives during storage.

The aim of this work is to reduce the incidence of the bloater spoilage in the fermented olives during storage, by the inhibition of yeasts without affecting the organoleptic characteristics of the olives.

\section{MATERIAL AND METHODS}

\subsection{Olives preparation}

Moroccan Picholine green olives, previously fermented with the Spanish style procedure, were sorted and distributed in 1 litre bottles $(600 \mathrm{~g}$ olives $/ 500$ $\mathrm{ml}$ of brine) at $5 \%$ of sodium chloride. The trials were separated in two groups. The first group (Trials 1, 2, 3, 4 \& 5) was acidified to $\mathrm{pH} 4$ and the second (Trials 6, 7, 8, $9 \& 10$ ) to $\mathrm{pH} 5$. After two days of brining the bottles, closed not anaerobically for simulating the industrial conditions, were treated as follow:

Trials 1 \& 6: controls

Trials 2 \& 7: inoculated with Pichia anomala S18

Trials 3 \& 8: inoculated with Pichia anomala S18 and Lactobacillus plantarum I159

Trials 4 \& 9: inoculated Pichia anomala S18 and added with Potassium sorbate $(0.05 \%)$

Trials 5 \& 10: inoculated with Pichia anomala S18 and L. plantarum I159 and added with Potassium Sorbate $(0.05 \%)$

The strain of $L$. plantarum I159 had been isolated from natural lactic fermentation of green olives (Asehraou et Faid 1993). Pichia anomala S18 strain had been isolated from bloatered green olives and characterized by a wide "killer" activity (Asehraou et al. 2000). This yeast strain was used in the assays to study the production of the "bloater" spoilage in the olives.

The inoculation of the olives, at $1 \%$ of the brine, was done by overnight cultures of L. plantarum I159 and $P$. anomala S18 made in MRS broth containing sodium chloride at $5 \%$.

The olives were inoculated without any previous heat treatment, and the trials made in duplicate were maintained at room temperature $\left(20-25^{\circ} \mathrm{C}\right)$ during the storage period for simulating the industrial conditions.

\subsection{Physico-chemical and microbiological analyses}

All the analyses were made on brine. $\mathrm{pH}$ values were determined by a $\mathrm{pH}$ meter type Crison $\mathrm{pH}$
2000. The Gram negative bacteria, lactic acid bacteria, and yeasts and moulds were determined respectively on Deoxycholate-Lactose-Agar (Biokar, France), MRS agar (Merk, Germany) (containing pimaricin at $0.02 \%$ ) and Potato-Dextrose-Agar (PDA) (Biokar, France) (acidified with lactic acid to $\mathrm{pH}: 3.5$ ). The Gram negative bacteria were counted after 2 days of incubation at $30^{\circ} \mathrm{C}$. The lactic population was counted after 3 days of incubation at $28^{\circ} \mathrm{C}$. The yeast and moulds population was counted after 3-4 days of incubation at $28^{\circ} \mathrm{C}$.

\subsection{Spoilage formation evaluation}

At the end of the storage, all the fruits of each trial were sorted handly and analysed visually to evaluate different deteriorations and their levels in the olives.

\section{RESULTS AND DISCUSSION}

The assays were stored for a period of 6 months, and during this period all the determinations were carried out. Results showed that during the 3 first months of storage, only the trials adjusted to $\mathrm{pH} 4$ and containing potassium sorbate (E4 and E5) had shown a stability of the $\mathrm{pH}$ between 3.81 and 3.9 (Fig.1 and Fig.2), while the other trials adjusted to $\mathrm{pH}$ 4 and 5 had shown a more or less rapid neutralisation of the brine. The slight acidification observed in the assays (pHs 4 and 5) after brining was due to the residual acids in the olives after the lactic fermentation.

After 6 months of storage the two trials E4 and E5 had shown a pH increase, with a delay in the trial E5, which had been inoculated with L. plantarum. This neutralization of the trials E4 and E5 would be due to the development of an upper film due to yeasts and moulds growth on the brines, during the last three months of the storage period.

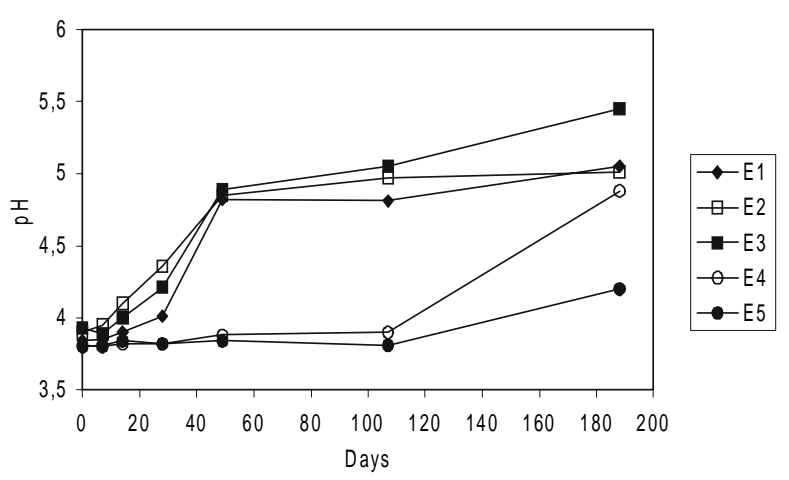

Figure 1

$\mathrm{pH}$ changes in fermented olives adjusted to $\mathrm{pH} 4$ during storage. 


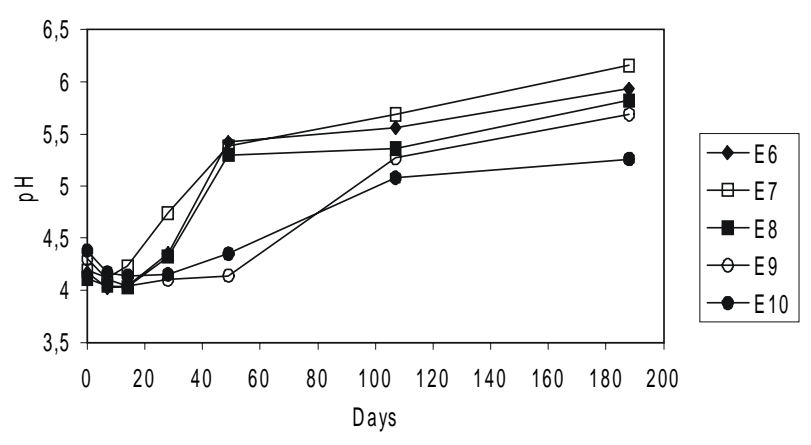

Figure 2

$\mathrm{pH}$ changes in fermented olives adjusted to $\mathrm{pH} 5$ during storage.

According to the scale of Balloni et al. (1975), only trials $\mathrm{E} 4$ and $\mathrm{E} 5$ (adjusted to $\mathrm{pH} 4$ and containing potassium sorbate) are microbiologically stable during the 3 first months. All the other trials are unstable or spoiled.

The two trials E4 and E5, which were microbiologically stable during the 3 first months of storage, had shown no growth of Gram negative bacteria during this period (Fig 3 and 4$)$. At the end of storage (6 months), only the trial inoculated with $L$. plantarum (E5) did not contain Gram negative bacteria, because of the brine acidification by the lactic strain. The uninoculated trial (E4) showed a reappearance of Gram negative bacteria, which is due to the rate of the brine neutralization by yeasts and moulds, forming a film on the brine. The high levels of Gram-negative bacteria populations shown in the other assays would be due to the high pHs $(\mathrm{pH}>\mathrm{H} 5)$ of their brines observed since the second month of storage.

In trials without sorbate, the yeasts and moulds populations showed variations between $10^{5}$ and 5.1 $10^{7} \mathrm{cfu} / \mathrm{ml}$ (Fig. 5, Fig. 6). The trials containing

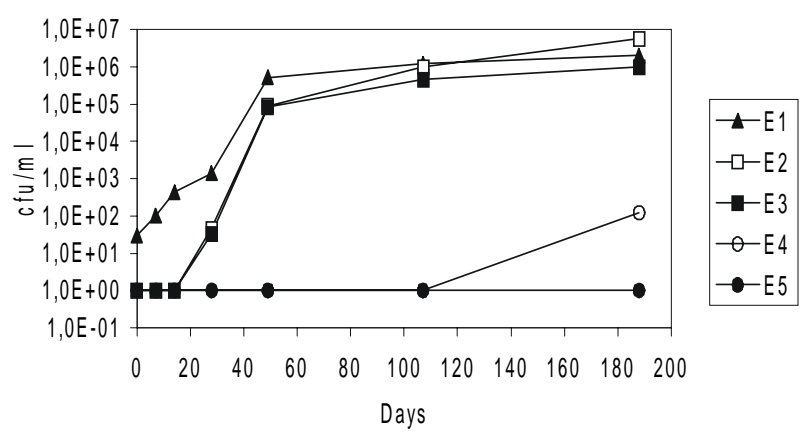

Figure 3

Gram negative bacteria profiles in fermented olives adjusted to $\mathrm{pH} 4$ during storage.

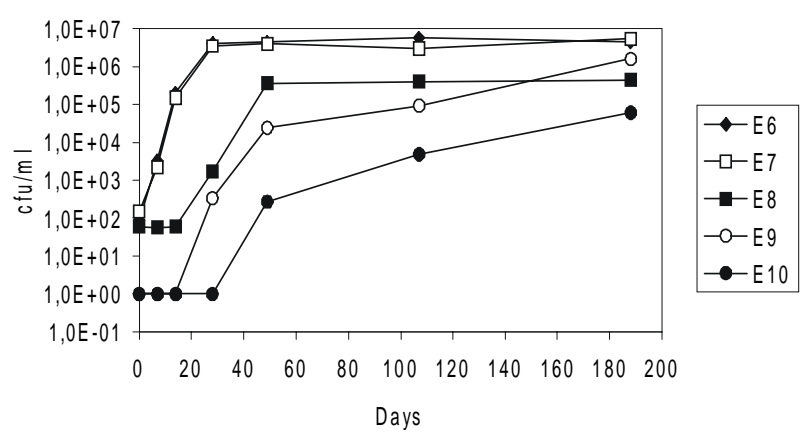

Figure 4

Gram negative bacteria population changes in fermented olives adjusted to $\mathrm{pH} 5$ during storage.

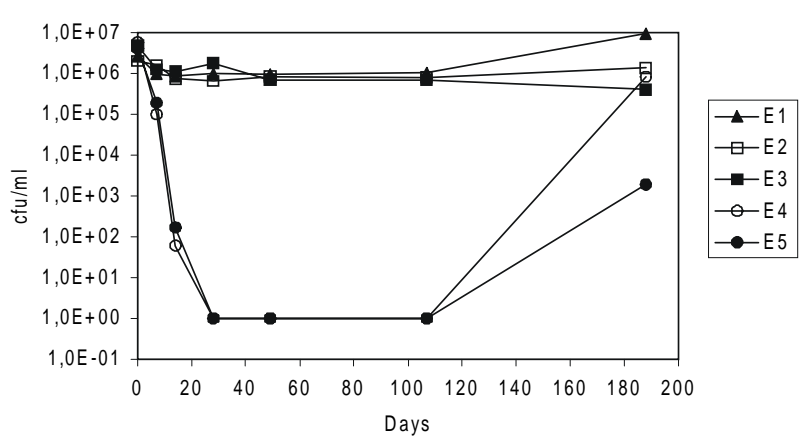

Figure 5

Yeasts and moulds profiles in fermented olives adjusted to $\mathrm{pH} 4$ during storage.

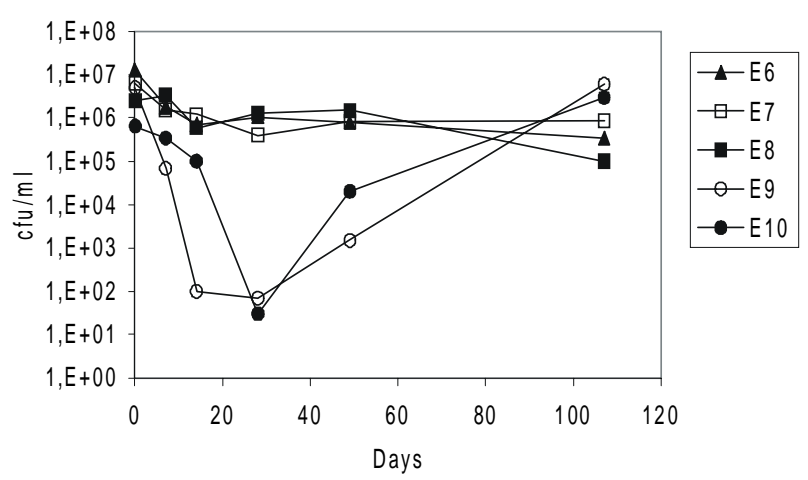

Figure 6

Yeasts and moulds profiles changes in fermented olives adjusted to $\mathrm{pH} 5$ during storage.

potassium sorbate (E4, E5, E9 and E10) showed a high decrease of yeasts and moulds populations because of the antifungal activity of potassium sorbate. Among these, trials adjusted to $\mathrm{pH} 5$ (E9 


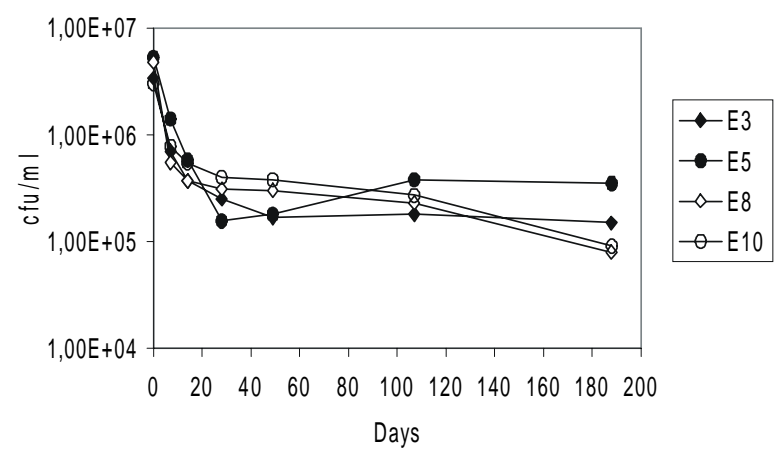

Figure 7

Lactic acid bacteria population changes in fermented olives during storage.

and E10) showed a rapid development of this microflora up to $5.910^{6}$ and $4.710^{5} \mathrm{cfu} / \mathrm{ml}$ respectively. But the trials adjusted to $\mathrm{pH} 4$ (E4 and E5) showed no growth of this microflora during the first 3 months of storage and reached $8.210^{5}$ and 1.9 $10^{3} \mathrm{cfu} / \mathrm{ml}$ respectively at the end of storage.

The trial inoculated with L. plantarum I159 (E5) showed a low development of yeasts and moulds in comparison with the non-inoculated trial (E4). Therefore the acidification of the medium by $L$. plantarum may activate the antifungal activity of sorbate. This would inhibit the yeasts and moulds and may reduce consequently the incidence of the bloater spoilage in olives.
The lactic population, especially $L$. plantarum I159 strain, had shown a decrease during the first days of the process reaching $10^{5}-510^{5} \mathrm{cfu} / \mathrm{ml}$ (Fig 7). This is due to the adaptation of the cells to the new conditions. This phase was followed by a slight development of the strains which continue to acidify the medium especially those acidified to $\mathrm{pH} 4$ and containing potassium sorbate.

The spoilage formation evaluation of the olives showed two defects namely lactic "spot" and "bloater" spoilage (Table I). The first defect is formed by the colonies of $L$. plantarum in the fruits stomates. This deterioration is less represented and it does not affect the organoleptic characteristics of the fruits.

The bloater spoilage was more abundant especially in trials adjusted to $\mathrm{pH} 5$. In comparison with the controls, trials inoculated with $P$. anomala, isolated from deteriorated fruits, showed high levels of bloater deterioration, except those adjusted to $\mathrm{pH}$ 4 and containing potassium sorbate (E4 and E5). These two trials had shown the lowest rates of this defect; $3.5 \%$ and $1.8 \%$ respectively for E4 and E5 (Table I); while the corresponding trials adjusted to $\mathrm{pH} 5$ (E9 and E10) showed respectively $40 \%$ and $48.8 \%$ as levels of bloatered fruits. This would be due to the antimicrobial activity of potassium sorbate, which is inversely proportional to the $\mathrm{pH}$ (Roussel and Gould, 1991).

The percentages of bloatered olives obtained in trials adjusted to $\mathrm{pH} 4$ and containing sorbate (E4 and E5) would be due to the $P$. anomala S18 strain

Table I

Spoilage evaluation of the olives at the end of the storage process

\begin{tabular}{|c|c|c|c|c|c|c|c|c|}
\hline \multirow[t]{2}{*}{ Trials } & \multicolumn{4}{|c|}{ "Bloater" (\%) } & \multicolumn{4}{|c|}{ "Lactic spot" (\%) } \\
\hline & assay 1 & assay 2 & $\mathrm{~m}$ & SD & assay 1 & assay 2 & $\mathrm{~m}$ & SD \\
\hline \multicolumn{9}{|l|}{ pH 4} \\
\hline E2 & 16.8 & 17.4 & $\begin{array}{l}9.0 \\
17.1\end{array}$ & 0.3 & $\begin{array}{l}2.1 \\
2\end{array}$ & 1.2 & 1.6 & 0.4 \\
\hline E3 & 10.2 & 11 & 10.8 & 0.2 & 7.8 & 7.2 & 7.5 & 0.3 \\
\hline E4 & 3.7 & 3.3 & 3.5 & 0.2 & 0.7 & 1.1 & 0.9 & 0.2 \\
\hline E5 & 2.1 & 1.5 & 1.8 & 0.3 & 9.4 & 8.8 & 9.1 & 0.3 \\
\hline \multicolumn{9}{|l|}{ pH 5} \\
\hline E6 & 24.5 & 25.1 & 24.8 & 0.3 & 2.2 & 1.6 & 1.9 & 0.3 \\
\hline E7 & 61.2 & 62.2 & 61.7 & 0.5 & 0.6 & 1.2 & 0.9 & 0.3 \\
\hline E8 & 53.3 & 52.7 & 53 & 0.3 & 2.9 & 2.5 & 2.7 & 0.2 \\
\hline E9 & 40.4 & 39.6 & 40 & 0.4 & 0.6 & 1 & 0.8 & 0.2 \\
\hline E10 & 49.1 & 48.5 & 48.8 & 0.3 & 4.2 & 4.8 & 4.5 & 0.3 \\
\hline
\end{tabular}

m: mean of the two assays, SD: standard deviation, E1 \& E6: controls, E2 \& E7: inoculated with Pichia anomala S18, E3 \& E8: inoculated with Pichia anomala S18 and Lactobacillus plantarum I159, E4 \& E9: inoculated with Pichia anomala S18 and added with Potassium sorbate (0.05\%), E5 \& E10: inoculated with Pichia anomala S18 and L. plantarum I159 and added with Potassium Sorbate $(0.05 \%)$ 
during the first days of storage, before its total inhibition (Durán Quintana et al., 1979).

The presence of $L$. plantarum in the brine is very important not only for reducing the residual sugars in the medium (competitiveness) but also for ensuring the continuous acidification of the brine, and consequently inhibiting the yeast growth (Leroi and Pidoux, 1993) which would produce carbon dioxide leading to bloaters formation in the olives.

Upon the foregoing the bloater level was drastically reduced by the conditions studied: brining at $5 \% \mathrm{NaCl}, \mathrm{pH}$ adjustment to 4 units, potassium sorbate addition (0.05\%) and L. plantarum 1159 inoculation. Fermented olives would stay with no change in their organoleptic characteristics during storage of 6 months under the already mentioned conditions. This period, which is longer than that found with Halkidiki and Intosso varieties (Marsilio and Cichelli, 1992), would be due to the low diffusion of potassium sorbate in the pulp of fruits and which may consequently contribute to the preservation of the olives from microorganisms growing in the brine.

This process is interesting not only for its long preservation of olives without affecting their organoleptic characteristics (color, odour, texture), but it had also an economic and environmental benefits because it does not require high salt concentration (only 5\%) and it reduces considerably the impact of brines rejected in the environment.

\section{REFERENCES}

Asehraou A. and Faid M. (1993). Etude physico-chimique et microbiologique des olives vertes désamérisées en fermentation. Actes Inst. Agron. Vet. (Maroc), 13, 21-26.

Asehraou A., Mohieddine S., Faid M. and Serhrouchni M. (1997). Use of antifungal principles from garlic for the inhibtion of yeasts and moulds in fermenting green olives. Grasas y Aceites, 48, 68-73.

Asehraou A., Peres C., Brito D., Faid M. and Serhrouchni M. (2000). Characterization of yeast strains isolated from bloaters of fermented green table olives during storage. Grasas y Aceites, 51, 225-229.

Balloni W., Brighigna A., Cucurachi A. and Florenzano G. (1975). Researches on the lactic acid bacteria of olives. Controlled fermentation experiments. Commission Internationale des Industries Agricoles et Alimentaires (C. I. I. A.). 12ème congrès International, Athènes. p: 421-445.

Duran Quintana M.C., Gonzalez Cancho F. y Garrido Fernandez A. (1979). Aceitunas negras al natural en salmuera. IX. Ensayos de producion de "alambrado" por inoculacion de diversos microorganismos aislados de salmuera de fermentacion. Grasas y Aceites, 30, 361-367.

Fleming H.P. (1982). Vegetable fermentations. In Economic Microbiology. Vol 7, Academic Press, Inc, London, England.

Garrido Fernandez A., Brenes Balbuena M., Garcia Garcia P. y Duran Quintana M.C. (1996). Conservación de aceitunas verdes o color cambiante en salmuera. Grasas y Aceites, 47, 197-206.

González Cancho F., Nosti Vega M., Fernández Diez M.J. y Buzcu N. (1970). Especies de Propionibacterium relacionadas con la "zapateria". Factores que influyen en su desarrollo. Microbiol. Espagn., 23, 233-252.

Leroi F. and Pidoux M. (1993). Detection of interactions between yeasts and lactic acid bacteria isolated from surgary kefir grains. J. Appl. Bacteriol., 74, 48-53.

Marsilio V. y Cichelli A. (1992). Influencia del sorbato potasico y del benzoato sodico sobre la estabilidad de las aceituna de mesa en salmuera. Grasas y Aceites, 43, 66-74.

Roussel N.J. and Gould G.W. (1991). Factors affecting growth and survival. In Food preservatives. pp 13-21. Edited by Roussel N.J. and Gould G.W. Blackie, London. 